\title{
Sex-Dependent Depression-Like Behavior Induced by Respiratory Administration of Aluminum Oxide Nanoparticles
}

\author{
Xin Zhang ${ }^{1, \dagger}{ }^{+}$, Yan $\mathrm{Xu}^{2,+}{ }^{+}$, Lian Zhou ${ }^{2}$, Chengcheng Zhang ${ }^{1}$, Qingtao Meng ${ }^{1}$, Shenshen $\mathrm{Wu}^{1}{ }^{1}$, \\ Shizhi Wang ${ }^{1}$, Zhen Ding ${ }^{2}$, Xiaodong Chen ${ }^{2}$, Xiaobo $\mathrm{Li}^{1, *}$ and Rui Chen ${ }^{1, *}$
}

Received: 14 September 2015; Accepted: 3 December 2015; Published: 9 December 2015

Academic Editor: Paul B. Tchounwou

1 Key Laboratory of Environmental Medicine Engineering, Ministry of Education, School of Public Health, Southeast University, Nanjing 210009, China; zx_ekin@163.com (X.Z.);

Zhangchengcheng2015@hotmail.com (C.Z.); mqtmengqingtao@hotmail.com (Q.M.); shenshenwu2015@hotmail.com (S.W.); shizhiwang2009@hotmail.com (S.W.)

2 Department of Environmental Health and Endemic Disease Control, Jiangsu Provincial, Center for Disease Prevention and Control, Nanjing 210009, China; cdcxy@vip.sina.com (Y.X.); jonneylian@163.com (L.Z.); jscdc@126.com (Z.D.); jscxd@126.com (X.C.)

* Correspondence: 101011116@seu.edu.cn (X.L.); 101011816@seu.edu.cn (R.C.); Tel.: +86-25-8327-2576 (X.L.); +86-25-8327-2560 (R.C.); Fax: +86-25-8327-2583 (X.L. \& R.C.)

+ These authors contributed equally to this work.

\begin{abstract}
Ultrafine aluminum oxide, which are abundant in ambient and involved occupational environments, are associated with neurobehavioral alterations. However, few studies have focused on the effect of sex differences following exposure to environmental $\mathrm{Al}_{2} \mathrm{O}_{3}$ ultrafine particles. In the present study, male and female mice were exposed to $\mathrm{Al}_{2} \mathrm{O}_{3}$ nanoparticles (NPs) through a respiratory route. Only the female mice showed depression-like behavior. Although no obvious pathological changes were observed in mice brain tissues, the neurotransmitter and voltage-gated ion channel related gene expression, as well as the small molecule metabolites in the cerebral cortex, were differentially modulated between male and female mice. Both mental disorder-involved gene expression levels and metabolomics analysis results strongly suggested that glutamate pathways were implicated in sex differentiation induced by $\mathrm{Al}_{2} \mathrm{O}_{3}$ NPs. Results demonstrated the potential mechanism of environmental ultrafine particle-induced depression-like behavior and the importance of sex dimorphism in the toxic research of environmental chemicals.
\end{abstract}

Keywords: depressive; nanoparticles; glutamate; aluminum oxide; sex difference

\section{Introduction}

Previous studies have indicated an association between adverse health effects and respiratory exposure to airborne ultrafine particulate matters with average aerodynamic diameter of up to $0.1 \mu \mathrm{m}[1,2]$. Given that the chemical components of particulate matters may vary with location, which may affect toxicity, the study of health associations of particle chemical constituents is critically required. Metals represent a portion of the elements found within airborne particulate matters (PM), which are important as they have high potential for chemical reactivity in vivo and in vitro [3]. Aluminum (Al) is one of the most consistent metal components of $\mathrm{PM}$ in the ambient environment $[4,5]$ and in the $\mathrm{Al}_{2} \mathrm{O}_{3}$ form it is relatively stable. Ultrafine $\mathrm{Al}_{2} \mathrm{O}_{3}$ particles are widely used in insulator layers, powder coatings, and fluorescent lamp reflecting materials. According to the Chinese Health standard for dusts of aluminum, aluminum oxide, and aluminum alloys in the air of workplace (GB11726-89), the maximum allowable concentration for $\mathrm{Al}_{2} \mathrm{O}_{3}$ is $6 \mathrm{mg} / \mathrm{m}^{3}$. Among these 
forms nanoscale $\mathrm{Al}_{2} \mathrm{O}_{3}$ particles could suspend longer in air and be uptaken through the respiratory tract. These ultrafine particles differ from the same conventional material in terms of physical, chemical, and biological characteristics; therefore, they are more likely to be toxic compared with same conventional-sized materials [6]. Once entering circulation, environmental ultrafine particles could induce impairments in other vital organs, such as the central nervous system. Thus, increased and inevitable occupational and ambient environment exposures to ultrafine $\mathrm{Al}_{2} \mathrm{O}_{3}$ particles may represent a health risk. $\mathrm{Al}$ is considered a neurotoxin. In a previous study we demonstrated that peripheral administration of $\mathrm{Al}_{2} \mathrm{O}_{3}$ nanoparticles (NPs) induced microglia and astrocyte activation in rat hippocampus and cortex [7]. In the present study, mice were exposed to $\mathrm{Al}_{2} \mathrm{O}_{3} \mathrm{NPs}$ through a whole-body exposure system, which mimics the actual exposure of suspended Al-containing ultrafine particles in air.

Stress is associated with the pathophysiology of emotional disorder, and women are more vulnerable to anxiety and depression in stress responses [8]. Numerous studies have explored the potential sex differentiation mechanisms; and studies have shown that glucocorticoids are released by the hypothalamus-pituitary-adrenals (HPA) axis more rapidly and intensively in stress responses in females than in males [9]. Hormones influence brain systems and lead to the gender differences of depression [8]. Exposure to environmental chemicals could induce brain dysfunction and depression-like alterations. A number of behavioral effects have been attributed to airborne PMs, including decreased spatial learning capability, spontaneous locomotion induced by diesel exhaust particles $[10,11]$, provoked depression-like responses induced by fine particulate matter $\left(\mathrm{PM}_{2.5}\right)$ coupled with light at night [12], and depression-like behavior induced by zinc oxide NPs [13]. However, gender differentiation was not noticed in those studies. Several studies have focused on association of behavior and the prenatal exposure to environmental PMs, which suggested a potential sex-differentiation. Prenatal exposure to urban air NPs caused depression-like responses in male offspring of mice [14]. Allen et al. [15] reported that ultrafine PMs induce autism-like alterations only in male offspring when exposed at an early postnatal stage. The potential mechanisms include increase of glia activation and enhanced hippocampal glutamate in male mice induced by the small particles existing in ambient environment.

The prefrontal cortex (PFC) plays an important role in several stress-related neuropsychiatric illnesses, including major depressive disorder. Reductions of volume in PFC were found in both bipolar and unipolar depressions [16,17], which are associated with glial loss and neuronal atrophy [18]. Decreased cortical glutamate and glial functions were involved in depression [19]. Bipolar disorders, including both depression and anxiety-like behavior, are observed after lesion formation in PFC [20].

To better understand the paradigm of sex-differentiated response to $\mathrm{Al}_{2} \mathrm{O}_{3} \mathrm{NPs}$, the present study evaluated mice behavior through open field test and forced swim tests as well as aluminum burden, gene expression and metabolites in cerebral cortex of mice administered by respiratory inhalation of $\mathrm{Al}_{2} \mathrm{O}_{3}$ NPs, which mimic the ambient exposure route, to help elucidate the sex-dependent response to environmental stress.

\section{Methods}

\subsection{Nanomaterial and Animals}

$\mathrm{Al}_{2} \mathrm{O}_{3} \mathrm{NPs}$ with an average diameter of $40 \mathrm{~nm}$ and $>99.8 \%$ purity were purchased from Plasmachem GmbH (Berlin, Germany). A total of 20 male and 20 female ICR mice (20-22 g) were purchased from Shanghai SLRC Laboratory Animal Co. Ltd. (Shanghai, China).

\subsection{Animal Treatment}

Animals were treated humanely, maintained, and used in accordance with Guidelines of Committee on Animal Use and Care of Southeast University. The entire body exposure chamber was 
fitted with extensive air quality monitoring equipment and an aerosol generator (Beijing HuiRongHe Technology Co., Ltd, Beijing, China). Mice were divided into four groups (with 10 mice in each group), namely male control, female control, male $\mathrm{Al}_{2} \mathrm{O}_{3} \mathrm{NP}$ treatment group, and female $\mathrm{Al}_{2} \mathrm{O}_{3} \mathrm{NP}$ treatment group. Mice were housed five per polycarbonate cage on corncob bedding with ad libitum access to food and water. Exposure was carried out in two whole-body exposure chambers at the same time; the treatment group received $\mathrm{Al}_{2} \mathrm{O}_{3} \mathrm{NPs}$, and the control received HEPA-filtered clean air at the same flow rate as the treatment group. Mice were placed in each chamber from 9 a.m. to 3 p.m. per day for 28 consecutive days. Light cycles were set on a 12/12 h light/dark cycle. The light cycle was maintained from 7 a.m. to 7 p.m. The mean concentrations of $\mathrm{Al}_{2} \mathrm{O}_{3} \mathrm{NPs}$ were $0.5 \mathrm{mg} / \mathrm{m}^{3}$, and temperature in the chambers was set to $22.5^{\circ} \mathrm{C}$.

\subsection{Open-Field Tests}

Emotional behavior of mice was determined using open field test (OFT) at 3 p.m. after 14 or 28 days $\mathrm{Al}_{2} \mathrm{O}_{3} \mathrm{NP}$ treatment. Animals were individually placed in an acrylic box $(40 \mathrm{~cm} \times 40 \mathrm{~cm})$ within a soundproof box and then placed on the apparatus for $3 \mathrm{~min}$. After the test, the mice were returned to their home cages. The open field was cleaned between tests. Behavior was recorded and analyzed with video tracking software (Ethovision XT, Noldus Information Technology, Wageningen, The Netherlands). Parameters including entries from periphery to central zones $(20 \mathrm{~cm} \times 20 \mathrm{~cm})$, duration in these two zones, speed, mobile and immobile durations, and total distance moved were analyzed.

\subsection{Forced Swimming Test}

Depression-like behavior of mice was determined by a forced swimming test (FST), which started 5 min after the end of OFT on the 28th day of $\mathrm{Al}_{2} \mathrm{O}_{3}$ NPs treatment. Each mouse was placed in a cylindrical tank with a diameter of $19 \mathrm{~cm}$ and height of $30 \mathrm{~cm}$. The tank was filled with tap water to the height of $25 \mathrm{~cm}$ and the temperature was maintained at $24 \pm 1^{\circ} \mathrm{C}$. Mice are considered immobile if they are floating and their hind limbs appear immobile, with only small visible movements of the forepaws to keep their head above water [21]. The behavior was recorded with a video camera for $5 \mathrm{~min}$. The total immobility duration was recorded by an observer blinded to the experiment design.

\subsection{RNA Isolation and Quantitative Real-Time PCR Assay}

Six mice per group were decapitated after ether anesthesia $24 \mathrm{~h}$ after the FST. The whole cortical tissue of brain was collected and kept in liquid nitrogen. Half of the cerebral cortex was prepared for total RNA extraction and the other half was kept for metabolomics analysis. The total RNA of brain tissues was extracted using a PureLink ${ }^{\circledR}$ RNA Mini Kit (Invitrogen, Carlsbad, CA, USA) according to the manufacturer's protocol. The concentration of total RNA was determined by measuring the absorbance at $260 \mathrm{~nm}$ using a Nanodrop 2000c spectrophotometer (Thermo Scientific, Waltham, MA, USA). cDNA synthesis for coding genes was performed with $1 \mu \mathrm{g}$ of total RNA according to the manufacturer's instruction (Toyobo, Osaka, Japan).

The modulated genes were screened based on previous mRNA microarray data (unpublished; Tables S1 and S2). The mRNA levels were determined by quantitative real-time PCR analysis (qRT-PCR) on a Quant Studio 6 Flex system (Applied Biosystems, Life Technologies, Carlsbad, CA, USA) using SYBR ${ }^{\circledR}$ Green Realtime PCR Master Mix-Plus (Toyobo, Osaka, Japan) in accordance with the manufacturer's protocol. Primers were designed for the modulated genes provided in supplemental Table S3. All experiments were performed in triplicates. The mRNA levels provided were normalized to cyclophilin A.

\subsection{Pathological Analysis}

Four mice per group were euthanized with ether anesthesia $24 \mathrm{~h}$ after the forced swimming test. Lungs and brains of mice were rapidly removed. A piece of lung and half brain tissues were 
fixed with $4 \%$ paraformaldehyde (PFA) overnight at $4{ }^{\circ} \mathrm{C}$, embedded in paraffin, serially sectioned $(5 \mu \mathrm{m})$, and then mounted on silane-covered slides. The other half brain and a piece of lung tissues were kept in liquid nitrogen for aluminum burden analysis. After dewaxing, the sections selected at corresponding layers from each mouse were stained with hematoxylin and eosin (H\&E). The severity of pathological lesions was scored according to Szapiel's method [22] as follow: 1= no appartent alveolitis; 2 = mild alveolitis (with pulmonary interstitial edema, inflammatory cell infiltration, and alveolar septum thickening, with lesions only local or limited to the subpleural area, which do not exceed $20 \%$ of the lung); 3 = moderate alveolitis (with the subpleural area more obvious, with the involved area more than $20 \%$ but less than $50 \%$ of the lung); $4=$ severe alveolitis (with lesions more than $50 \%$ of the lung, with inflammatory cells inside the alveolar cavity and consolidation changes). Double-blind examination of alveolitis was conducted by an experienced pathologist using a light microscope, and the alveolitis scores were presented as a mean for each sample.

\subsection{Aluminum Burden}

The cortex and midbrain were separated from the half brain of mice. Then, the brain and lung samples were weighed.Approximately $0.05 \mathrm{~g}$ of each sample was digested with HNO3 in a boiling water bath for $3 \mathrm{~h}$. The aluminum burdens in different brain regions were quantified using an inductively coupled plasma mass spectrometry (ICP-MS, Agilent 7700, Santa Clara, CA, USA).

\subsection{Metabolomics Analysis}

Metabolomics analysis was performed according to the report of Xu et al. [23]. Briefly, to each mouse cortex sample was added $50 \%$ methanol $(1 \mathrm{~mL})$ and it was homogenized, and the supernatant was obtained after centrifugation at $12,000 \mathrm{rpm}$ for $15 \mathrm{~min}$. About $350 \mu \mathrm{L}$ of the supernatant was transferred into a $2 \mathrm{~mL}$ vial and blow-dried by nitrogen. Afterward, $80 \mu \mathrm{L}$ of methoxyamine was added and reacted for $2 \mathrm{~h}$ at $37^{\circ} \mathrm{C}$. Finally, $100 \mu \mathrm{L}$ of bis (trimethylsilyl)trifluoroacetamide (BSTFA) reagent (containing $1 \%$ TMCS) was added to the mixture and reacted for $60 \mathrm{~min}$ at $70{ }^{\circ} \mathrm{C}$. The sample was cooled down to room temperature and then analyzed by GC/TOF/MS (Agilent 7890 coupled with a Pegasus $4 \mathrm{D}$ TOF). $1 \mu \mathrm{L}$ of the sample was injected in split less mode at a gas flow rate of $1 \mathrm{~mL} / \mathrm{min}$. The program was set at $80^{\circ} \mathrm{C}$ for $0.2 \mathrm{~min}$, raised to $180^{\circ} \mathrm{C}$ at a rate of $10^{\circ} \mathrm{C} / \mathrm{min}$, then to $240{ }^{\circ} \mathrm{C}$ at a rate of $5^{\circ} \mathrm{C} / \mathrm{min}$, and finally to $290^{\circ} \mathrm{C}$ at a rate of $20^{\circ} \mathrm{C} / \mathrm{min}$.

\subsection{Data Analysis}

Data are presented as the mean \pm standard error of the mean. Statistical analyses were conducted using SPSS 16.0. Two-way ANOVA followed by Student's $t$-test was used to compare the parameters of aluminum burden and fold induction of gene expression. Two-way repeated measures ANOVA, with sex as independent factors and duration of exposure as within-subjects factor was used to compare the parameters of behavioral studies on treatment day 14 and 28. Kruskal-Wallis test was used to analyze the ranked data of pulmonary alveolitis. The significance was set as $p<0.05$. Two-way ANOVA followed by Bonferroni post hoc comparisons was performed in metabolomics analysis. The cut-off for metabolomics analysis is fold change $>1.5$ and $p<0.05$.

\section{Results}

\subsection{Female Mice Demonstrated Depressive-Like Behavior Following $\mathrm{Al}_{2} \mathrm{O}_{3} \mathrm{NP}$ Exposure.}

In OFT, $\mathrm{Al}_{2} \mathrm{O}_{3} \mathrm{NPs}$ treated female mice exhibited less duration in the central zone and enhanced duration in peripheral zone which implied less exploring behavior and spontaneous locomotion [13] compared with female control after 14 days-treatment $(t=7.098, \mathrm{df}=9, p<0.00001)$ (Figure 1A) and 28 days of treatment $(t=9.777, \mathrm{df}=9, p<0.00001)$ (Figure $1 \mathrm{~B}$ ). 
OFT on treatment day 14

A

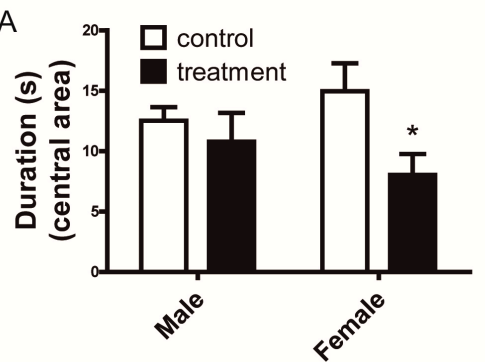

OFT on treatment day 14

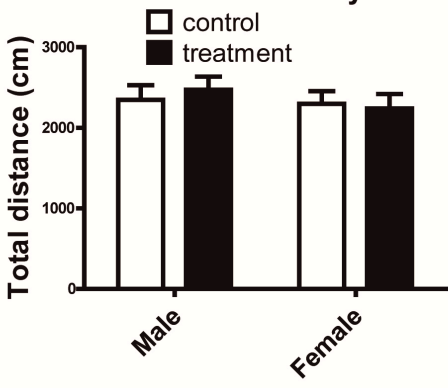

B

OFT on treatment day 28

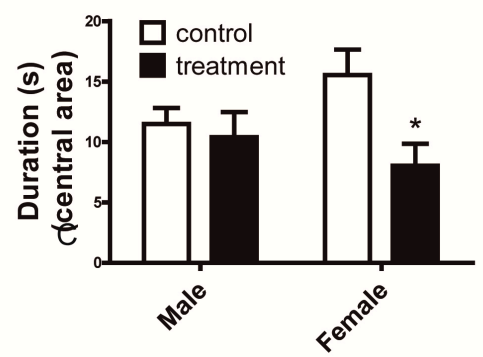

C

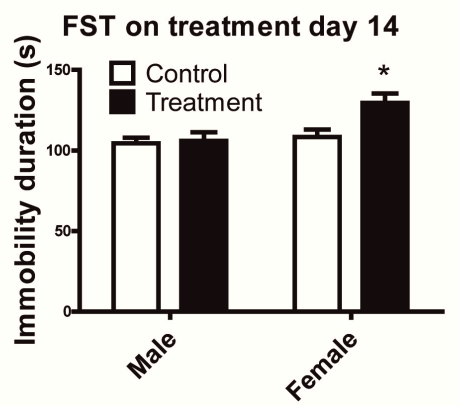

OFT on treatment day 14

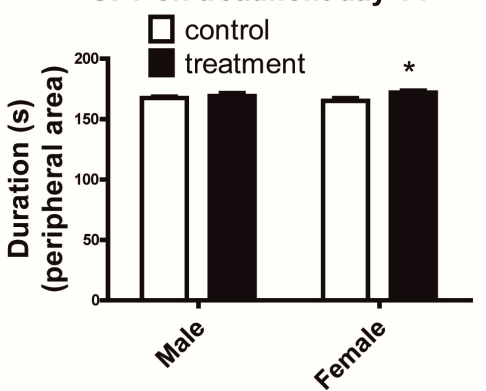

OFT on treatment day 14

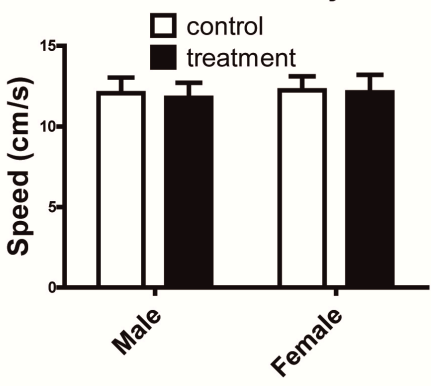

OFT on treatment day 28
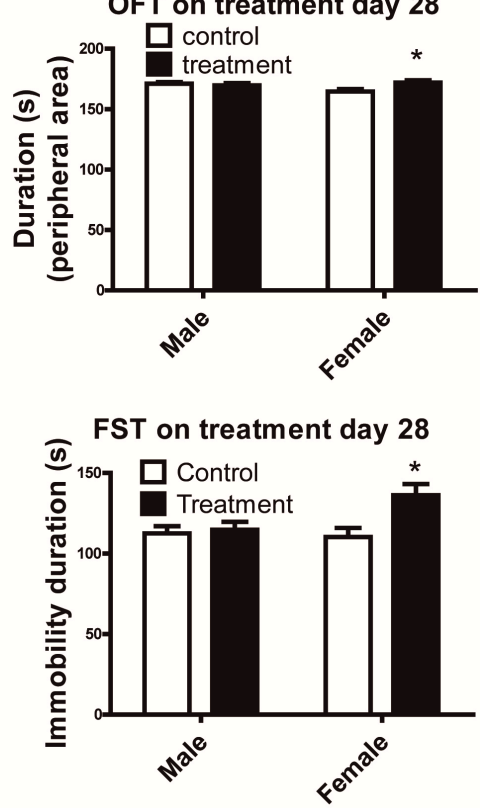

Figure 1. Emotional behavioral tests of mice treated by $\mathrm{Al}_{2} \mathrm{O}_{3}$ NPs. (A): female mice showed less duration in central zone and increased duration in periphery zone in OFT on treatment day 14, (B): On the treatment day 28 , results were consistent with day $14,(\mathbf{C})$ : female mice showed increased immobile duration in FST on treatment day 14 and 28. ${ }^{*} p<0.05$, compared with control of corresponding sex, $\mathrm{n}=10$.

Male mice did not show significant differences between control and treatment (Figure 1A,B). Female mice exposed to $\mathrm{Al}_{2} \mathrm{O}_{3}$ NPs had higher immobility time during the 5 min FST than female control after $14(t=8.692, \mathrm{df}=9, p<0.00001)$ or $28(t=7.558, \mathrm{df}=9, p<0.00001)$ days of treatment (Figure $1 \mathrm{C}$ ). Consistent with the OFT, mice treated with $\mathrm{Al}_{2} \mathrm{O}_{3} \mathrm{NPs}$ did not show any behavioral alterations in FST (Figure 1C). The interaction effects between sex and $\mathrm{Al}_{2} \mathrm{O}_{3}$ NPs treatment were showed in central area duration $(\mathrm{F}=14.17, p=0.0008$ on day $14 ; \mathrm{F}=37.56, p<0.0001$ on day 28, $\mathrm{df}=9)$, peripheral area duration $(\mathrm{F}=14.17 p=0.0008$ on day $14 ; \mathrm{F}=37.56, p<0.0001$ on day 28 , 
$\mathrm{df}=9)$ and immobility duration $(\mathrm{F}=32.39, p<0.0001$ on day $14 ; \mathrm{F}=25.18, p<0.0001$ on day 28 , $\mathrm{df}=9$ ) following 14 or 28 days of treatment.

For OFT and FST, the data following 14 and 28 days of treatment were compared through two-way repeated measures ANOVA, with sex as independent factors and duration of exposure as within-subjects factor. However, there were no significant differences between 14- and 28-day observations (for OFT central area duration $\mathrm{F}=1.780, p=0.1929$; peripheral area duration $\mathrm{F}=1.780$, $p=0.1929$; for FST F $=0.2518, p=0.6197$ ).

\subsection{Aluminum Burden Varied in Brain and Lung Tissues of Mice}

Results in Figure 2 demonstrate that the aluminum burden in the lung tissues of $\mathrm{Al}_{2} \mathrm{O}_{3} \mathrm{NP}$-treated mice significantly increased compared with their corresponding sex control (for male mice, $t=18.290, \mathrm{df}=3, p<0.00001$; for female mice, $t=18.700, \mathrm{df}=3, p<0.00001$ ).

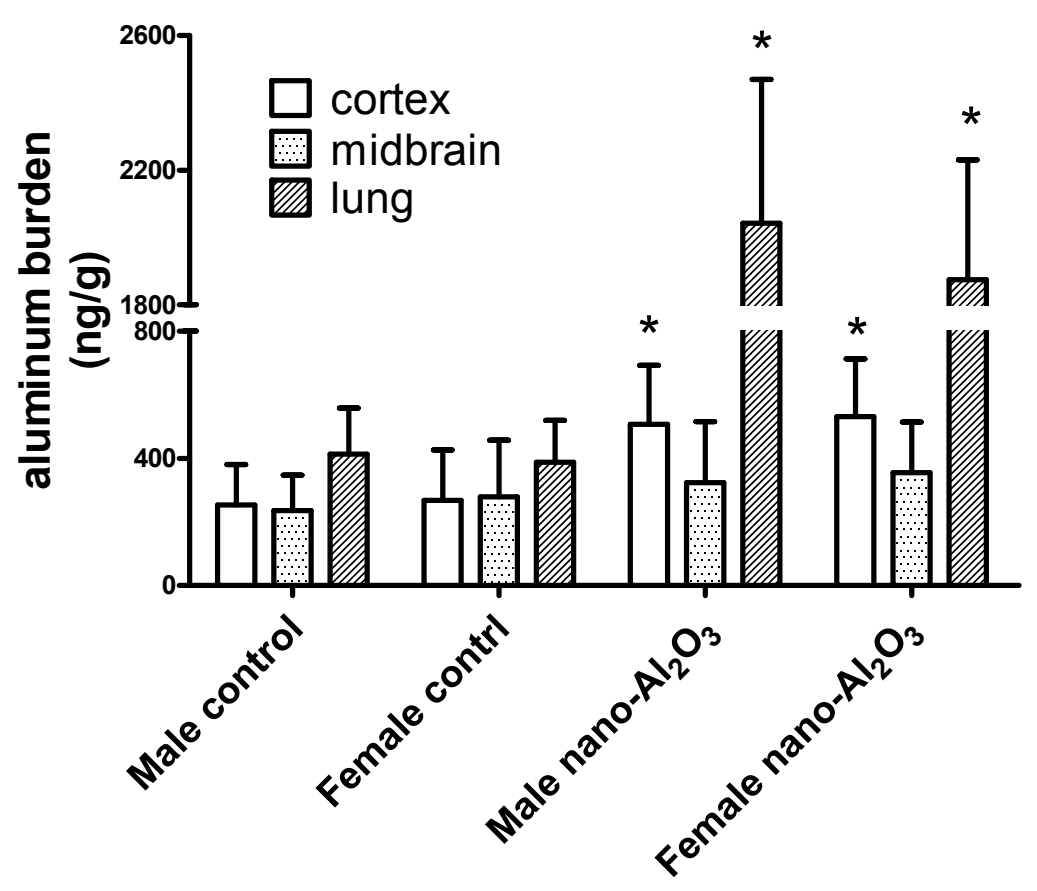

Figure 2. Aluminum burden in cortex, midbrain, and lung tissues of mice. ${ }^{*} p<0.05$, compared with the corresponding sex control, $\mathrm{n}=4$.

Similar trends of enhancement were noted in the cortex but not midbrain (for male mice, $t=2.845, \mathrm{df}=3, p=0.01125$; for female mice, $t=3.316, \mathrm{df}=3, p=0.0042$ ). The aluminum concentrations between male and female in the same tissue were also compared. No significant sex-dependent differences were observed, therefore, the increased aluminum burden in cortex of mice could not account for the differences of neurobehaviors between male and female mice. More investigations on the underlying mechanisms in mice brains are required.

\subsection{Pathological Alterations of Lung but not Brain Tissues of Mice Were Observed}

Lesions in lung tissues were scored (seen in Table 1). Both male and female mice showed mild to moderate alveolitis ( $2.25 \pm 0.50$ for male mice, $2.5 \pm 0.58$ for female mice) following $\mathrm{Al}_{2} \mathrm{O}_{3} \mathrm{NP}$ exposure compared with corresponding sex control (for male mice $p<0.0001$; for female mice $p<0.0001$ ). No differences were observed between male and female $\mathrm{Al}_{2} \mathrm{O}_{3} \mathrm{NP}$-treated mice. Figure $3 \mathrm{~A}$ shows lung tissue of control group. Figure $3 \mathrm{~B}$ shows ruptured alveolar walls and fusion of pulmonary alveoli. Figure $3 \mathrm{C}$ demonstrates pneumorrhagia in lung tissues. Figure 3D shows 
lymphocyte infiltration in lung tissues. No significant pathological alterations were observed in the brain cortex.

Table 1. Severity of lesions in lung tissues response to nano $\mathrm{Al}_{2} \mathrm{O}_{3}$ treatment.

\begin{tabular}{|c|c|c|c|c|c|}
\hline \multirow{2}{*}{ Group } & \multicolumn{4}{|c|}{ Lesion Severity Grade } & \multirow{2}{*}{$\begin{array}{c}\text { Average } \\
\text { Severity Grade }\end{array}$} \\
\hline & 1 & 2 & 3 & 4 & \\
\hline male control & 4 & & & & 1 \\
\hline female control & 4 & & & & 1 \\
\hline male nano- $\mathrm{Al}_{2} \mathrm{O}_{3}$ & & 3 & 1 & & $2.25 \pm 0.50 *$ \\
\hline female nano- $\mathrm{Al}_{2} \mathrm{O}_{3}$ & & 2 & 2 & & $2.5 \pm 0.58 *$ \\
\hline
\end{tabular}

${ }^{*} p<0.05$, compared with the corresponding sex control, $\mathrm{n}=4$.
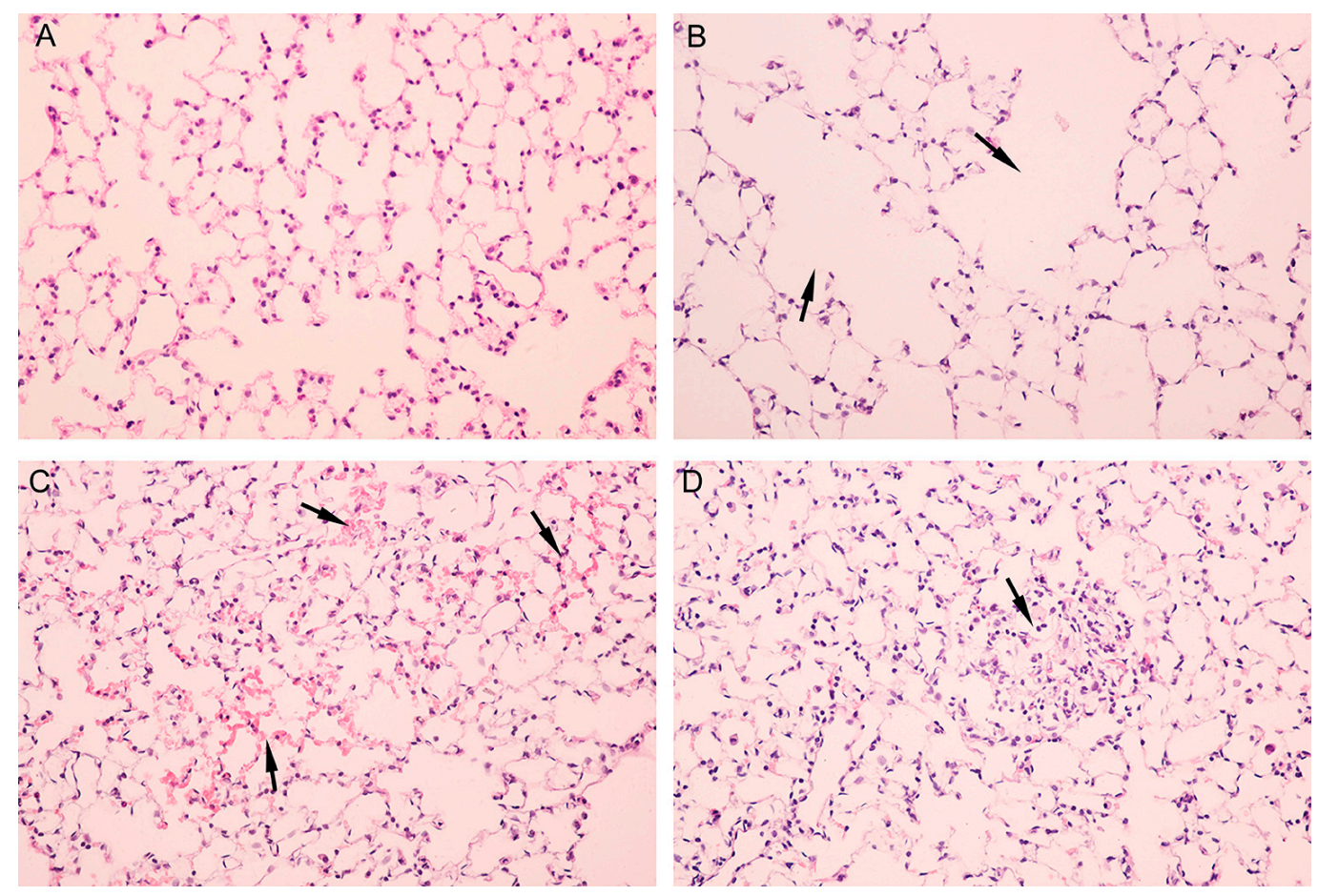

Figure 3. Pathology of mice lung tissues following $\mathrm{Al}_{2} \mathrm{O}_{3}$ treatment. (A): control; (B): arrows showed ruptured alveolar walls and fusion of pulmonary alveoli; (C): arrows showed pneumorrhagia in lung tissues; (D): arrows demonstrated lymphocyte infiltration in lung tissues.

\subsection{Expressions of Mental Disorder Involved Genes Were Modulated in a Sex-Dependent Manner}

To further elucidate the potential mechanism of sex-dependent neurobehavioral alterations induced by $\mathrm{Al}_{2} \mathrm{O}_{3} \mathrm{NPs}$, the expression levels of mental disorder-related genes were detected by qRT-PCR. The expression levels of 16 genes in mice cerebral cortex were validated by qRT-PCR (Table 2). Ten genes, including SNAP29, ZDHHC8, GDNF, GNAS, NOS3, GRIN2A, DGKH, MT2A, ACNA1G and KCNQ showed interaction effects between sex and $\mathrm{Al}_{2} \mathrm{O}_{3} \mathrm{NP}$ treatment $(p<0.05)$.We noticed that these sex-differentially expressed genes were involved with neurotransmitter, phosphatidic acid synthesis, and voltage-gated ion channels, which occupied important positions in neural functions. Most of the predicted downregulated gene expressions in the mice cortex were consistent with the array data. These genes were significantly downregulated in both male and female brain tissues. The expression levels of DGKH, CACNA19, MT2A, and KCNQ2 in male mice were enhanced $(p<0.05)$, whereasGRIN2A was not significantly modulated. In female 
mice cerebral cortex, the expressions of MT2A and GRIN2A were upregulated $(p<0.05)$, whereas the levels of DGKH, CACNA1G, and KCNQ2 were significantly downregulated $(p<0.05)$.

\subsection{Metabolomics Analysis Explored the Potential Role of Glutamate}

Bonferroni post hoc comparisons were used to identify the key small molecules alterations. A total of 10 different expression metabolites were identified in the cortex of male mice including seven upregulated and three downregulated; 12 modulated metabolites were found in the cortex of female mice including eight upregulated and four downregulated. Notably, two glutamate metabolism-related molecules, L-glutamic acid and pyroglutamic acid, decreased in female tissues, which showed an inconsistent trend with male. The list of modulated metabolites, their corresponding human metabolome database (HMDB) ID and fold change are shown in Table 3. 
Table 2. Fold induction of modulated genes in mice cortex.

\begin{tabular}{|c|c|c|c|c|c|c|c|c|c|c|}
\hline & \multicolumn{2}{|c|}{ Control } & \multicolumn{2}{|c|}{ Treatment } & \multirow{2}{*}{\multicolumn{3}{|c|}{ F Value }} & \multirow{2}{*}{\multicolumn{3}{|c|}{$p$ Value }} \\
\hline & Male & Female & Male & Female & & & & & & \\
\hline & Fold Change & Fold Change & Fold Change & Fold Change & Treatment & Sex & Interaction & Treatment & Sex & Interaction \\
\hline SNAP29 & $1.03 \pm 0.10$ & $1.02 \pm 0.12$ & $0.95 \pm 0.11$ & $0.62 \pm 0.14^{*, \#}$ & 24.64 & 12.36 & $10.95^{\&}$ & $<0.0001$ & 0.0022 & 0.0035 \\
\hline UFD1L & $1.01 \pm 0.07$ & $1.02 \pm 0.06$ & $0.61 \pm 0.08 *$ & $0.65 \pm 0.08$ * & 167.00 & 0.7042 & 0.2535 & $<0.0001$ & 0.4113 & 0.6201 \\
\hline ZDHHC8 & $1.04 \pm 0.05$ & $1.05 \pm 0.07$ & $0.95 \pm 0.07 *$ & $0.58 \pm 0.06^{*, \#}$ & 131.40 & 41.09 & 46.23 \& & $<0.0001$ & $<0.0001$ & $<0.0001$ \\
\hline PDLIM5 & $1.01 \pm 0.08$ & $1.05 \pm 0.10$ & $0.71 \pm 0.10$ * & $0.82 \pm 0.14$ * & 36.64 & 2.935 & 0.639 & $<0.0001$ & 0.1022 & 0.4334 \\
\hline HSPA1A & $1.06 \pm 0.10$ & $0.99 \pm 0.07$ & $0.54 \pm 0.11 *$ & $0.56 \pm 0.09 *$ & 154.30 & 0.4273 & 1.385 & $<0.0001$ & 0.5207 & 0.2531 \\
\hline PTEN & $0.99 \pm 0.08$ & $1.03 \pm 0.09$ & $0.63 \pm 0.11 *$ & $0.67 \pm 0.12 *$ & 75.86 & 0.94 & 0.00 & $<0.0001$ & 0.3447 & 1.0000 \\
\hline GDNF & $1.01 \pm 0.07$ & $0.98 \pm 0.05$ & $0.65 \pm 0.06$ * & $0.32 \pm 0.14$ *,\# & 204.00 & 25.41 & 17.65 \& & $<0.0001$ & $<0.0001$ & 0.0004 \\
\hline SOD2 & $0.97 \pm 0.06$ & $0.99 \pm 0.08$ & $0.67 \pm 0.12 *$ & $0.56 \pm 0.07$ * & 109.10 & 1.66 & 3.46 & $<0.0001$ & 0.2125 & 0.0776 \\
\hline GNAS & $1.01 \pm 0.09$ & $1.06 \pm 0.12$ & $0.88 \pm 0.15$ & $0.70 \pm 0.14^{*, \#}$ & 22.30 & 1.57 & $4.91^{\&}$ & 0.0001 & 0.2247 & 0.0384 \\
\hline NOS3 & $0.96 \pm 0.11$ & $1.00 \pm 0.04$ & $0.71 \pm 0.08 *$ & $0.93 \pm 0.15^{\#}$ & 14.42 & 9.52 & 4.56 \& & 0.0011 & 0.0058 & 0.0452 \\
\hline DLST & $1.01 \pm 0.04$ & $0.97 \pm 0.06$ & $0.91 \pm 0.12$ & $0.87 \pm 0.06$ & 10.34 & 1.66 & 0.00 & 0.0043 & 0.2130 & 1.0000 \\
\hline GRIN2A & $0.97 \pm 0.08$ & $1.01 \pm 0.06$ & $1.10 \pm 0.18$ & 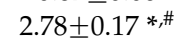 & 423.70 & 317.70 & $288.20 \&$ & $<0.0001$ & $<0.0001$ & $<0.0001$ \\
\hline DGKH & $1.01 \pm 0.04$ & $1.06 \pm 0.09$ & $2.14 \pm 0.09 *$ & $0.72 \pm 0.06$ *\# & 175.00 & 526.21 & $605.94 \&$ & $<0.0001$ & $<0.0001$ & $<0.0001$ \\
\hline MT2A & $1.01 \pm 0.07$ & $1.02 \pm 0.15$ & $1.98 \pm 0.07 *$ & $2.34 \pm 0.13$ *\#\# & 639.50 & 16.70 & 14.94 \& & 0.0010 & 0.0006 & $<0.0001$ \\
\hline CACNA1G & $1.04 \pm 0.07$ & $1.03 \pm 0.06$ & $2.77 \pm 0.13 *$ & $0.75 \pm 0.12$ *\# & 516.75 & 938.68 & 887.50 \& & $<0.0001$ & $<0.0001$ & $<0.0001$ \\
\hline KCNQ & $1.00 \pm 0.04$ & $0.97 \pm 0.08$ & $2.86 \pm 0.10^{*}$ & $0.72 \pm 0.11$ *\#\# & 317.03 & 621.19 & $609.14^{\&}$ & $<0.0001$ & $<0.0001$ & $<0.0001$ \\
\hline
\end{tabular}

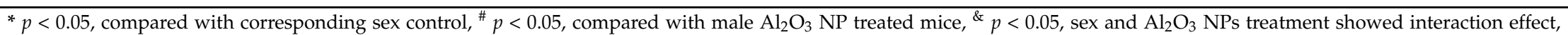

$\mathrm{df}=5$. 
Table 3. Metabolomics analysis of $\mathrm{Al}_{2} \mathrm{O}_{3} \mathrm{NP}$-treated mice cortex.

\begin{tabular}{|c|c|c|c|c|c|c|c|c|}
\hline \multirow[t]{2}{*}{ Metabolite } & \multirow[t]{2}{*}{ HMDB ID } & \multicolumn{3}{|c|}{ Fold Change } & \multicolumn{2}{|c|}{$\begin{array}{l}\text { Male } \mathrm{Al}_{2} \mathrm{O}_{3} \mathrm{NPs} v s . \\
\text { Male Control }\end{array}$} & \multicolumn{2}{|c|}{$\begin{array}{c}\text { Female } \mathrm{Al}_{2} \mathrm{O}_{3} \mathrm{NPs} \\
\text { vs. Male Control }\end{array}$} \\
\hline & & Male $\mathrm{Al}_{2} \mathrm{O}_{3} \mathrm{NPs}$ & Female Control & Female $\mathrm{Al}_{2} \mathrm{O}_{3} \mathrm{NPs}$ & F Value & $p$ Value & F Value & $p$ Value \\
\hline L-Serine & HMDB00187 & 1.98 & 1.03 & $4.26^{\#}$ & 13.63 & 0.002 & 53.54 & $<0.0001$ \\
\hline Dihydroxy acetone Phosphate & HMDB01473 & - & 0.83 & 2.97 \# & 0.43 & 0.5261 & 14.9 & 0.0017 \\
\hline Inosine & HMDB00195 & 2.05 & 1.14 & 2.61 & 12.68 & 0.0022 & 13.01 & 0.0019 \\
\hline Prostaglandin E2 & HMDB01220 & 2.43 & 1.27 & 4.02 & 22.31 & 0.0001 & 49.69 & $<0.0001$ \\
\hline Acetyl-L-Carnitine & HMDB00201 & 2.37 & 0.96 & 3.86 & 28.74 & $<0.0001$ & 37.21 & $<0.0001$ \\
\hline Pyroglutamic Acid & HMDB00267 & 2.53 & 0.89 & $0.52^{\#}$ & 32.57 & $<0.0001$ & 24.52 & $<0.0001$ \\
\hline Riboflavin & HMDB00244 & 3.83 & 1.07 & 2.18 & 36.53 & $<0.0001$ & 27.73 & $<0.0001$ \\
\hline Inosine 5-Monophosphate & HMDB00175 & 1.89 & 0.93 & 1.68 & 11.42 & 0.0026 & 9.52 & 0.0058 \\
\hline L-Glutamic Acid & HMDB00148 & - & 1.08 & $0.17^{\#}$ & 1.69 & 0.2125 & 103.89 & $<0.0001$ \\
\hline 7b-Hydroxycholesterol & HMDB06119 & 0.48 & 0.77 & - & 28.49 & $<0.0001$ & 0.89 & 0.4213 \\
\hline 2-Hydroxyestrone & HMDB00343 & -10 & 0.98 & 0.48 & 0.25 & 0.6178 & 41.25 & $<0.0001$ \\
\hline Dl-Glyceraldehyde & HMDB01051 & 0.3 & 1.06 & 0.46 & 59.77 & $<0.0001$ & 38.56 & $<0.0001$ \\
\hline Petroselinic Acid & HMDB02080 & 0.21 & 1.18 & 0.48 & 75.86 & $<0.0001$ & 42.59 & $<0.0001$ \\
\hline
\end{tabular}




\section{Discussion}

In this study, we observed that respiratory inhalation of $\mathrm{Al}_{2} \mathrm{O}_{3} \mathrm{NPs}$ increased depression-like behavior only in female mice. Gene expression and metabolomics analysis implied strong modulations of glutamate pathway in a sex-dependent manner.

Behavioral tests demonstrated decreased spontaneous locomotion, exploring behaviors and increased despair-like behavior in female mice exposed to $\mathrm{Al}_{2} \mathrm{O}_{3} \mathrm{NPs}$. Environmental ultrafine particles were associated with depression-like behavior. The potential mechanisms included oxidative stress, lipid peroxidation, and disruption of electrophysiological processes [13,24]. Differences between genders were not mentioned in previous studies. Prenatal exposure to NPs collected from urban air also induces depression-like responses, but only in male offspring [15]. The variation of chemicals and exposure time window may affect behavioral outcomes. In the present study, exposure duration did not show interaction with behavioral alterations. Further studies are still required to explore whether a longer exposure could aggravate the damages of behaviors induced by $\mathrm{Al}_{2} \mathrm{O}_{3}$ treatment.

Aluminum burden in the cortex and midbrain of mice was examined. Significant increases were noted in the lung and cortex tissues of $\mathrm{Al}_{2} \mathrm{O}_{3} \mathrm{NP}$-treated mice of both sexes, suggesting that aluminum particles could reach brain tissues through respiratory exposure. However, this enhancement of aluminum burden in the cortex region could not explain the sex-dependent differences in depression-like behavior of mice. These data implied that aluminum existing in cortex could trigger a different profile of biological responses in male and female, thus warranting investigation of the underlying molecular correlations. Furthermore, we assessed the gene expression levels and alterations of metabolites to explore the potential sex-dependent depression mechanism.

The voltage-sensitive calcium channel, which is encoded by CACNA1G, mediates the entry of calcium ions into excitable cells and is also involved in various calcium-dependent processes such as neurotransmitter release, cell division, and cell death. KCNQ2 encodes subfamily Q of potassium-voltage-gated channel, which plays a critical role in the regulation of neuronal excitability. Voltage-gated channels contribute to the regulation of diverse neuronal functions through elevating intracellular ion concentrations $[25,26]$. The defects in the expression or modulation of presynaptic ion channels may result in neural network dysfunction. The heterozygous rol/+ rolling mice showed less immobility time than the wild type $(+/+)$, which is attributed to the presence of calcium channel subunit mutation [21]. We found that two voltage-gated ion channel-related genes, CACNA1G and $\mathrm{KCNQ2}$, were differently regulated in male and female mice exposed to $\mathrm{Al}_{2} \mathrm{O}_{3}$ NPs. This implied that down-regulation of voltage-gated ion channels is associated with depressive-like behavior in female mice.

DGKH encodes a member of the diacylglycerol kinase enzyme family and plays a key role in promoting cell growth. Variation in this gene is associated with bipolar disorder [27] and unipolar depression [28]. Results showed a sex-dependent regulation in DGKH expression.

Metabolomics analysis help to understand the endogenous small molecules alteration induced by $\mathrm{Al}_{2} \mathrm{O}_{3} \mathrm{NPs}$, and the results also suggest effects in a sex-dependent manner. L-Glutamic acid, one of the most abundant fast excitatory neurotransmitters in the mammalian nervous system, is suggested to play a key role in depression development. Once released by presynaptic cells, glutamic acid binds and activates glutamate receptors including NMDA receptor. Increased expression of NMDA receptor was observed in major depression patients [29,30]. Our qRT-PCR results showed significantly upregulated GRIN2A in $\mathrm{Al}_{2} \mathrm{O}_{3}$ NPs treated female mice cortex, which is a glutamate (NMDA) receptor subunit-encoding gene. Pyroglutamic acid is a cyclized derivative of L-glutamic acid. Altered pyroglutamic levels imply disruption of glutamine metabolism. Interestingly, down-regulation of L-glutamic acid was observed only in female mice cortex, and pyroglutamic acid increased in male but decreased in female mice cortex treated with $\mathrm{Al}_{2} \mathrm{O}_{3} \mathrm{NPs}$. Depressive disorder is associated with altered function of excitatory neurotransmitter glutamate; reduced glutamate levels were observed in depressive patients or in animal models [31,32]. 
Up-regulation of GRIN2A was observed in dorsolateral prefrontal cortex of female major depressive disorder cases, which is consistent with our results [30]. In the present study, differential regulation of glutamate pathway-related metabolites was observed in a sex-dependent manner. In addition to upregulation of glutamate receptor subunit GRIN2A in female mice, our results strongly suggested that the glutamate pathway was involved in the $\mathrm{Al}_{2} \mathrm{O}_{3} \mathrm{NP}$-induced depression-like behavior in female mice.

One of the limitations in the present study was that only the filtered clean air control was set to observe the toxic effects of exposure to $\mathrm{Al}_{2} \mathrm{O}_{3} \mathrm{NPs}$. Thus, current results could not elucidate whether the damages observed as a result of chemical or mechanical effects of exposure. One more group exposed to aluminum particles would provide insight to determine whether the phenotype observed in this study resulted from exposure to aluminum or the nanoparticles themselves. The other limitation of our study was that whole cortex tissue but not PFC were used for the gene expression, metabolomics and aluminum burden analysis. Due to the small volume of mice brains, PFC tissues are not enough for these analyses. Thus, more mice and better experimental design should be provided in the further studies.

\section{Conclusions}

In brief, metabolomics analysis coupled with the modulated gene expression in mice cerebral cortex explored sex-dependent' alterations in mice treated with $\mathrm{Al}_{2} \mathrm{O}_{3} \mathrm{NPs}$, including the neural behavior, voltage-gate ion channels, neural transmitter, and small molecule metabolisms. These results could partly explain the sex-dependent response to environmental stress and prompt the importance of sexual dimorphism in environmental toxin research.

Acknowledgments: This work was financially supported by National Natural Science Foundation of China (Grant No. 81472938), the Fund of the Distinguished Talents of Jiangsu Province (BK20150021), the Natural Science Foundation of Jiangsu Province (BK20151418), the Open Research Fund of State Key Laboratory of Bioelectronics, Southeast University, the Fund of the Post-graduate Innovative Talents (Grant No. SJZZ_0033), and the Fundamental Research Funds for the Central Universities.

Author Contributions: Xiaobo Li and Rui Chen conceived and designed the experiments; Xin Zhang, Lian Zhou, Chengcheng Zhang, Qingtao Meng and Shenshen Wu performed the experiments, Shizhi Wang and Yan Xu analyzed the data; Zhen Ding and Xiaodong Chen contributed analysis tools; Xiaobo Li wrote the paper.

Conflicts of Interest: The authors declare no conflict of interest.

\section{References}

1. Nogueira, J.B. Air pollution and cardiovascular disease. Rev. Port. Cardiol. 2009, 28, 715-733. [PubMed]

2. Corbin, J.C. $\mathrm{PM}_{0.1}$ particles from aircraft may increase risk of vascular disease. BMJ 2013, 347. [CrossRef] [PubMed]

3. Gavett, S.H.; Haykal-Coates, N.; Copeland, L.B.; Heinrich, J.; Gilmour, M.I. Metal composition of ambient $\mathrm{PM}_{2.5}$ influences severity of allergic airways disease in mice. Environ. Health Perspect. 2003, 111, 1471-1477. [CrossRef] [PubMed]

4. Veranth, J.M.; Kaser, E.G.; Veranth, M.M.; Koch, M.; Yost, G.S. Cytokine responses of human lung cells (BEAS-2B) treated with micron-sized and nanoparticles of metal oxides compared to soil dusts. Part. Fiber Toxicol. 2007, 4. [CrossRef] [PubMed]

5. Reff, A.; Bhave, P.V.; Simon, H.; Pace, T.G.; Pouliot, G.A.; Mobley, J.D.; Houyoux, M. Emissions inventory of $\mathrm{PM}_{2.5}$ trace elements across the United States. Environ. Sci. Technol. 2009, 43, 5790-5796. [CrossRef] [PubMed]

6. Mills, N.L.; Donaldson, K.; Hadoke, P.W.; Boon, N.A.; MacNee, W.; Cassee, F.R.; Sandstrom, T.; Blomberg, A.; Newby, D.E. Adverse cardiovascular effects of air pollution. Nat. Clin. Pract. Cardiovasc. Med. 2009, 6, 36-44. [CrossRef] [PubMed]

7. Li, X.B.; Zheng, H.; Zhang, Z.R.; Li, M.; Huang, Z.Y.; Schluesener, H.J.; Li, Y.Y.; Xu, S.Q. Glia activation induced by peripheral administration of aluminum oxide nanoparticles in rat brains. Nanomedicine 2009, 5, 473-479. [CrossRef] [PubMed] 
8. Young, E.; Korszun, A. Sex, trauma, stress hormones and depression. Mol. Psychiatry 2010, 15, $23-28$. [CrossRef] [PubMed]

9. Galea, L.A.; McEwen, B.S.; Tanapat, P.; Deak, T.; Spencer, R.L.; Dhabhar, F. Sex differences in dendritic atrophy of CA3 pyramidal neurons in response to chronic restraint stress. Neuroscience 1997, 81, 689-697. [CrossRef]

10. Yokota, S.; Takashima, H.; Ohta, R.; Saito, Y.; Miyahara, T.; Yoshida, Y.; Negura, T.; Senuma, M.; Usumi, K.; Hirabayashi, N.; et al. Nasal instillation of nanoparticle-rich diesel exhaust particles slightly affects emotional behavior and learning capability in rats. J. Toxicol. Sci. 2011, 36, 267-276. [CrossRef] [PubMed]

11. Suzuki, T.; Oshio, S.; Iwata, M.; Saburi, H.; Odagiri, T.; Udagawa, T.; Sugawara, I.; Umezawa, M.; Takeda, K. In utero exposure to a low concentration of diesel exhaust affects spontaneous locomotor activity and monoaminergic system in male mice. Part. Fibre Toxicol. 2010, 7. [CrossRef] [PubMed]

12. Hogan, M.K.; Kovalycsik, T.; Sun, Q.; Rajagopalan, S.; Nelson, R.J. Combined effects of exposure to dim light at night and fine particulate matter on $\mathrm{C} 3 \mathrm{H} / \mathrm{HeNHsd}$ mice. Behav. Brain Res. 2015, 294, 81-88. [CrossRef] [PubMed]

13. Xie, Y.; Wang, Y.; Zhang, T.; Ren, G.; Yang, Z. Effects of nanoparticle zinc oxide on spatial cognition and synaptic plasticity in mice with depressive-like behaviors. J. Biomed. Sci. 2012, 19. [CrossRef] [PubMed]

14. Davis, D.A.; Bortolato, M.; Godar, S.C.; Sander, T.K.; Iwata, N.; Pakbin, P.; Shih, J.C.; Berhane, K.; McConnell, R.; Sioutas, C.; Finch, C.E.; Morgan, T.E. Prenatal exposure to urban air nanoparticles in mice causes altered neuronal differentiation and depression-like responses. PLoS ONE 2013, 8. [CrossRef] [PubMed]

15. Allen, J.L.; Liu, X.; Pelkowski, S.; Palmer, B.; Conrad, K.; Oberdorster, G.; Weston, D.; Mayer-Proschel, M.; Cory-Slechta, D.A. Early postnatal exposure to ultrafine particulate matter air pollution: Persistent ventriculomegaly, neurochemical disruption, and glial activation preferentially in male mice. Environ. Health Perspect. 2014, 122, 939-945. [CrossRef] [PubMed]

16. Drevets, W.C.; Price, J.L.; Simpson, J.R., Jr.; Todd, R.D.; Reich, T.; Vannier, M.; Raichle, M.E. Subgenual prefrontal cortex abnormalities in mood disorders. Nature 1997, 386, 824-827. [CrossRef] [PubMed]

17. Sheline, Y.I. Neuroimaging studies of mood disorder effects on the brain. Biol. Psychiatry 2003, 54, 338-352. [CrossRef]

18. Banasr, M.; Duman, R.S. Regulation of neurogenesis and gliogenesis by stress and antidepressant treatment. CNS Neurol. Disord. Drug Targets 2007, 6, 311-320. [CrossRef] [PubMed]

19. Choudary, P.V.; Molnar, M.; Evans, S.J.; Tomita, H.; Li, J.Z.; Vawter, M.P.; Myers, R.M.; Bunney, W.E., Jr.; Akil, H.; Watson, S.J.; Jones, E.G. Altered cortical glutamatergic and GABAergic signal transmission with glial involvement in depression. Proc. Natl. Acad. Sci. USA 2005, 102, 15653-15658. [CrossRef] [PubMed]

20. Klein, J.; Winter, C.; Coquery, N.; Heinz, A.; Morgenstern, R.; Kupsch, A.; Juckel, G. Lesion of the medial prefrontal cortex and the subthalamic nucleus selectively affect depression-like behavior in rats. Behav. Brain Res. 2010, 213, 73-81. [CrossRef] [PubMed]

21. Takahashi, E.; Niimi, K.; Itakura, C. Emotional behavior in heterozygous rolling mouse Nagoya Ca v 2.1 channel mutant mice. Neurobiol. Aging 2011, 32, 486-496. [CrossRef] [PubMed]

22. Szapiel, S.V.; Elson, N.A.; Fulmer, J.D.; Hunninghake, G.W.; Crystal, R.G. Bleomycin-induced interstitial pulmonary diseases in the nude, athymic mouse. Am. Rev. Respir. Dis. 1979, 120, 893-899. [PubMed]

23. Xu, B.; Chen, M.; Ji, X.; Mao, Z.; Zhang, X.; Wang, X.; Xia, Y. Metabolomic profiles delineate the potential role of glycine in gold nanorod-induced disruption of mitochondria and blood-testis barrier factors in TM-4 cells. Nanoscale 2014, 6, 8265-8273. [CrossRef] [PubMed]

24. Cui, Y.; Chen, X.; Zhou, Z.; Lei, Y.; Ma, M.; Cao, R.; Sun, T.; Xu, J.; Huo, M.; Cao, R.; Wen, C.; Che, Y. Prenatal exposure to nanoparticulate titanium dioxide enhances depressive-like behaviors in adult rats. Chemosphere 2014, 96, 99-104. [CrossRef] [PubMed]

25. Liu, L.; Zwingman, T.A.; Fletcher, C.F. In vivo analysis of voltage-dependent calcium channels. J. Bioenerg. Biomembr. 2003, 35, 671-685. [CrossRef] [PubMed]

26. Berridge, M.J.; Lipp, P.; Bootman, M.D. The versatility and universality of calcium signalling. Nat. Rev. Mol. Cell Biol. 2000, 1, 11-21. [CrossRef] [PubMed]

27. Whalley, H.C.; Papmeyer, M.; Romaniuk, L.; Johnstone, E.C.; Hall, J.; Lawrie, S.M.; Sussmann, J.E.; McIntosh, A.M. Effect of variation in diacylglycerol kinase eta (DGKH) gene on brain function in a cohort at familial risk of bipolar disorder. Neuropsychopharmacology 2012, 37, 919-928. [CrossRef] [PubMed] 
28. Weber, H.; Kittel-Schneider, S.; Gessner, A.; Domschke, K.; Neuner, M.; Jacob, C.P.; Buttenschon, H.N.; Boreatti-Hummer, A.; Volkert, J.; Herterich, S.; et al. Cross-disorder analysis of bipolar risk genes: Further evidence of DGKH as a risk gene for bipolar disorder, but also unipolar depression and adult ADHD. Neuropsychopharmacology 2011, 36, 2076-2085. [CrossRef] [PubMed]

29. Sequeira, A.; Mamdani, F.; Ernst, C.; Vawter, M.P.; Bunney, W.E.; Lebel, V.; Rehal, S.; Klempan, T.; Gratton, A.; Benkelfat, C.; et al. Global brain gene expression analysis links glutamatergic and GABAergic alterations to suicide and major depression. PLoS ONE 2009, 4. [CrossRef] [PubMed]

30. Gray, A.L.; Hyde, T.M.; Deep-Soboslay, A.; Kleinman, J.E.; Sodhi, M.S. Sex differences in glutamate receptor gene expression in major depression and suicide. Mol. Psychiatry 2015, 20, 1057-1068. [CrossRef] [PubMed]

31. Hasler, G.; van der Veen, J.W.; Tumonis, T.; Meyers, N.; Shen, J.; Drevets, W.C. Reduced prefrontal glutamate/glutamine and gamma-aminobutyric acid levels in major depression determined using proton magnetic resonance spectroscopy. Arch. Gen. Psychiatry 2007, 64, 193-200. [CrossRef] [PubMed]

32. Chiba, S.; Numakawa, T.; Ninomiya, M.; Richards, M.C.; Wakabayashi, C.; Kunugi, H. Chronic restraint stress causes anxiety- and depression-like behaviors, downregulates glucocorticoid receptor expression, and attenuates glutamate release induced by brain-derived neurotrophic factor in the prefrontal cortex. Prog. Neuropsychopharmacol. Biol. Psychiatry 2012, 39, 112-119. [CrossRef] [PubMed]

(C) 2015 by the authors; licensee MDPI, Basel, Switzerland. This article is an open access article distributed under the terms and conditions of the Creative Commons by Attribution (CC-BY) license (http:/ / creativecommons.org/licenses/by/4.0/). 